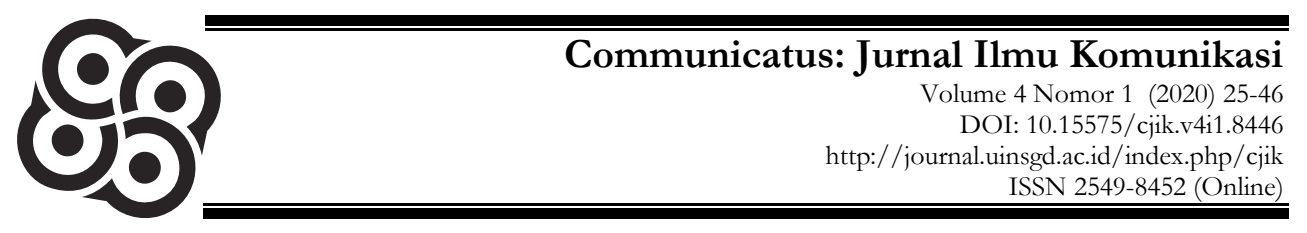

\title{
Literasi Jurnalisme Kelompok Informasi Masyarakat Kabupaten Bandung
}

\author{
Ujang Saefullah ${ }^{1} * \&$ Dudi Rustandi ${ }^{2}$ \\ ${ }^{1}$ UIN Sunan Gunung Djati Bandung \\ 2Politeknik LP3I Bandung \\ *email.ujang.saefullab@uinsgd.ac.id
}

\begin{abstract}
The research aims to; (1) Knowing the existence of KIM Bandung Regency, (2) Understanding the literacy of KIM journalism in Bandung Regency; (2) Knowing and understanding in journalism practices of KIM members in Bandung Regency. Research using descriptive methods, case study approach. The conceptual/ theoretical approach uses news elements and news values that form the basis of journalism. While the techniques of collecting data through observation, interviews, and Google form. The results showed (1) the existence of the KIM Bandung Regency was initiated in 2016, which was initiated by the Office of Communication and Information of Bandung Regency, supported in 2019 with the formation of management and facilitation of KIM media in the form of websites and social media. (2) understanding of KIM member journalists' literacy is good (3) A small number of KIM members have practiced journalism well, but most are still far from journalism criteria. Through this research, it is expected that this will affect the literacy increase of KIM members, both in Bandung Regency and KIM throughout Indonesia.
\end{abstract}

Keywords: literacy; journalism, community information group.

\begin{abstract}
ABSTRAK
Penelitian bertujuan untuk; (1) Mengetahui eksistensi KIM Kabupaten Bandung, (2) Memahami literasi jurnalisme KIM Kabupaten Bandung; (2) Mengetahui dan memahami pemahaman dalam praktik jurnalisme anggota KIM Kabupaten Bandung. Penelitian menggunakan metode deskriptif, pendekatan studi kasus. Pendekatan secara konsep/teori menggunakan unsur berita dan nilai berita yang menjadi dasar dari jurnalisme. Sedangkan teknik pengumpulan datanya melalui observasi, wawancara, dan googleform. Hasil penelitian menunjukkan (1) eksistensi KIM Kabupaten Bandung diinisasi tahun 2016, yang dinisiasi oleh Dinas Komunikasi dan Informatika Kabupaten Bandung, didukung pada tahun 2019 dengan pemebtukan pengurus serta fasilitasi media KIM berupa website dan media sosial. (2) pemahaman terhadap literasi jurnalis anggota KIM sudah baik (3) Sebagian kecil anggota KIM telah mempraktikkan jurnalisme dengan baik, namun sebagian besar masih jauh dari kriteria jurnalisme. Melalui penelitian ini diharapkan bedampak terhadap peningkatan literasi anggota KIM, baik di Kabupaten Bandung ataupun KIM seluruh Indonesia.
\end{abstract}

Kata kunci: literasi, jurnalisme, kelompok informasi masyarakat. 
Ujang Saefullah \& Dudi Rustandi

\section{PENDAHULUAN}

Pemerintah tidak dapat bekerja sendiri dalam membangun daerahnya tanpa partisipasi dari warganya. Era jejaring digital, bentuk pertisipasi dapat dimaksimalkan melalui kehadiran kelompok informasi masyarakat yang langsung bersentuhan dengan akar rumput. Melalui teknologi yang telah memasyarakat, perangat selular, memanfaatkan dan memaksimalkan nilai gunanya dapat mendorong pembangunan suatu daerah.

Eksistensi kelompok informasi masyarakat (disingkat KIM) merupakan amanat pemerintah berdasarkan Peraturan Menkominfo No. 08/PER/M.KOMINFO/6/2010 tentang Pedoman Pengembangan dan Pemberdayaan Lembaga Komunikasi Sosial. Menurut peraturan tersebut, KIM merupakan kelompok yang dibentuk oleh, dari, untuk masyarakat secara mandiri dan kreatif yang aktivitasnya melakukan pengelolaan informasi dan pembdayaan masyarakat dalam rangka meningkatkan nilai tambah. Peraturan tersebut menyebut KIM sebagai Lembaga Komunikasi Pedesaan (Kemenkominfo, 2010).

Melalui peraturan tersebut, lembaga komunikasi yang berada pada tingkat desa memiliki posisi yang sama dengan lembaga lain di tingkat yang lebih atas misalnya kabupaten atau provinsi karena sama-sama memiliki peran dalam mewujudkan masyarakat yang produktif dan mandiri.

Pemerintah sendiri terus mendorong agar tumbuh kesadaran menjadi masyarakat mandiri informasi dengan berbagi dan memberdayakan informasi di lingkungannya sendiri. Salah satu daerah yang terus mendorong dan support terhadap KIM adalah kabupaten Bandung.

Sejak tahun 2016 Kabupaten Bandung terus menggalakan eksistensi kelompok informasi masyarakat hingga terbentuknya KIM tingkat Kabupaten secara legal tahun 2019. Melalui Dinas Komunikasi dan Informasi, Pemerintah Kabupaten Bandung terus mendorong agar anggota KIM Kabupaten Bandung memiliki keterampilan dalam menyampaikan informasi melalui saluran yang tersedia, baik web desa ataupun situs web kelompok informasi masyarakat yang telah disediakan oleh pemerintah.

Kelompok informasi masyarakat memiliki misi mengembangkan, memberdayakan, memfasilitasi, mendinamisasi pelayanan informasi untuk anggota masyarakat. seperti ditulis oleh situs kelompok informasi masyarakat kabupaten Badung (kim.badungkab.go.id). Hal ini juga merujuk pada Permen No 08/PER/M.KOMINFO/6/2010 tentang Pedoman Pengembangan dan Pemberdayaan Lembaga Komunikasi Sosial (Kemenkominfo, 2010).

Kelompok Informasi merupakan kelompok yang dibentuk oleh, dari, untuk masyarakat yang dikembangkan dengan mandiri dan kreatif, aktivitasnya melakukan pengelolaan informasi dan pembeedayaan masyarakat dalam rangka meningkatkan value di masyarakat. Hal ini seperti ditulis dalam situs web KIM 
Kabupaten Kolaka (kim.kolakakab.go.id).

Berdasarkan data pra observasi, KIM Kabupaten Bandung telah difasilitasi domain web melalui kim.bandungkab.go.id. Untuk mendorong agar anggota KIM terus produktif dan informatif dalam memberikan pelayanan informasi daerahnya (desa), Dinas Komunikasi dan Informasi Kabupaten Bandung terus membekali anggota KIM dengan berbagai keterampilan. Keterampilan tersebut berupa wawasan dasar jurnalistik, fotografi, blogging, termasuk juga mendorong agar pengurus KIM Kabupatn Bandung terus mendorong anggotanya aktif dan melakukan pemberdayaan informasi di daerahnya masing-masing.

Penelitian tentang Kelompok informasi masyarakat sendiri pernah dilakukan oleh Mulyono Yalia (Yalia, 2015) tentang Implementasi Kebijakan dan Pemberdayaan KIM di Kabupaten Pangandaran yang memokuskan pada implementasi kebijakan pengembangan dan pemberdayaan KIM. Menggunakan teori implementasi kebijakan dari Jones, penelitian tersebut menghasilkan bahwa dalam melaksanaan kebijakan pemerintah mengenai pemberdayaan lembaga komunikasi sosial, yang dilakukan pemerintah daerah Pangandaran Jawa Barat, maka penting melakukan pengawasan dan koordinasi di luar implementasi kebijakan.

Penelitian lain tentang KIM berjudul Pembentukan Kelompok Informasi Masyarakat Kelurahan Gadingkasri, Kota Malang (Yudhistiro \& Sonalitha, 2019). Hasil penelitian menunjukkan, kehadiran KIM dapat memudahkan akses informasi dan data terkait dengan persoalan dalam masyarakat. Kehadiran KIM di kelurahan Gadingkasri memberikan ifnromasi dan data berbasis web.

Aldie Kusnan Faillah dan Rinda Cahyana melakukan penelitian tentang Pengembangan Portal Web Kelompok Informasi Masyarakat di Kabupaten Garut. Penelitian tersebut berhasil mengembangkan portal web Kelompok Informasi Masyarakat menggunakan metode waterfall memanfaatkan teknologi digital wall information dan peta Google. Portal ini sangat menunjang interaksi antara anggota KIM dalam berbagi informasi wilayah dan kontennya (Fadillah \& Cahyana, 2017).

Penelitian lain dilakukan oleh Sari, tentang implementasi program KIM di Jawa Timur (KIM Nglanduk dan KIM Warurejo) Dan Wilayah Urban (KIM Mojo dan KIM Swaraguna). Hasil Penelitiannya, Sari menyimpulkan bahwa kondisi masyarakat Jawa Timur tersebut jauh harapan dari terwujudnya masyarakat informasi. Masyarakat masih berada jauh di bawah tingkat sadar informasi, untuk wilayah rural banyak yang kurang sadar terhadap pentingnya informasi. Menurutnya karena implementasi program tidak optimal dan terkendala beragam masalah (Sari, 2017).

Sedangkan tentang peranan Kelompok Informasi Masyarakat, penelitiannya dilakukan oleh Nur Azizah. Azizah melakukan penelitan tentang 
Ujang Saefullah \& Dudi Rustandi

Difusi Inovasi terkait peranan KIM Swara Ringgit Kelurahan Ledug Guna meningkakan Potensi Lokal. Terkait dengan penelitian tersebut, hasilnya menujukkan bahwa inovasi memperkenalkan dan mempromosikan produk lokal melalui internet melalui lima tahap, yaitu: tahap yakni Knowledge (pengetahuan), persuasion (bujukan/ajakan) decision (pengambilan keputusan) serta implementation (i mplementasi/pelaksanaan) dan confirmation (konfirmasi). Proses adopsi inovasi dalam penelitian ini berjalan lancar dan baik. Inovasi dapat diterima oleh masyarakat (Azizah, 2018).

Penerapan jurnalisme oleh kelompok informasi masyarakat pernah dilakukan oleh Nadya Yudo Wiranti dan Gilang Gusti Aji. Penelitian ini memperlihatkan bahwa praktik jurnalisme anggota Kelompok Informasi Masyarakat Kota Surabaya relevansinya sangat kuat dalam merealisasikan information society. Jurnalisme warga yang diterapkan juga tidak lepas dari penyampaian aspirasi dari masyarakat kepada pemerintah sebagai wujud demokrasi. Beberapa media Informasi yang digunakan mulai dari web, Video, media sosial, tatap muka. Kelompok Informasi Masyarakat pada wilayah tersebut menggiatkan masyarakat agar beradaptasi dengan dunia maya, karena pada konteks ini informasi menjadi kebutuhan utama. Adaptasi tersebut dilakukan melalui penyuluhan dan pelatihan (Wiranti \& Aji, 2019).

Berdasarkan beberapa penelitian terdahulu, yang membahas tentang implementasi kebijakan, pengembangan portal web KIM, implementasi program KIM, peranan KIM, dan praktik jurnalisme dalam mendorong masyarakat informasi, penelitian ini lebih fokus terhadap literasi jurnalisme, tidak hanya sekadar praktik jurnalismenya tapi pemahaman terkait peran, fungsi, serta kognisi dan empati dari jurnalisme. Point ini menjadi pembeda antara penelitian terdahulu dengan penelitian yang dilakukan oleh penulis.

Eksistensi kelompok informasi masyarakat khususnya terkait dengan literasi jurnalisme perlu ditindaklanjuti karena posisinya cukup signifikan di tengah-tengah masyarakat sebagai agen informasi. Peneliti menginisiasi isunya dengan mengangkat tema Literasi Jurnalisme Bagi Anggota Kelompok Informasi Masyarakat Kabupaten Bandung. Adapun permasalahan yang dapat diidentifikasi; (1) Bagamana eksistensi KIM Kabupaten Bandung; (2) Bagaimana Pemahaman Literasi Jurnalisme Anggota KIM Kabupate Bandung, (3) Bagaimana praktik jurnalisme anggota KIM Kabupaten Bandung dari perspektif literasi jurnalisme.

Penelitian ini diharapkan memberikan kontribusi tentang pentingnya jurnalisme bagi agen informasi di luar jurnalis profesional. Karena bagaimanapun anggota kelompok informasi masyarakat, bersentuhan dengan persoalanpersoalan dinamika informasi di masyarakat. Adapun manfaat penelitian ini, dapat dijadikan sebagai bahan rujukan bagi penelitian sejenis di masa yang akan datang, juga menjadi penguatan akan pentingnya literasi jurnalisme bagi kelompok informasi masyarakat lain di kabupaten atau kota lain di Indonesia. 
Adapun kebaruan penelitian ini, karena menyoroti praktik penyebaran informasi melalui kacamata jurnalisme. Jika dirujuk pada penelitian sebelumnya, belum ada peneliti yang melakukan penelitian ini, kecuali yang dilakukan oleh Wiranti dan Aji (2019), itu pun perspektif jurnalisme warga.

Adapun penelitian ini bertujuan adalah (1) Mengetahui eksistensi KIM Kabupaten Bandung, (2) Memahami literasi jurnalisme KIM Kabupaten Bandung; (3) Mengetahui dan memahami pemahaman dalam praktik jurnalisme anggota KIM Kabupaten Bandung. Penelitian ini menggunakan metode deksriptif dengan pendekatan studi kasus dengan pendekatan konsep jurnalisme. Ada pun teori yang digunakan terkait dengan penelitian ini adalah konsepkonsep literasi; pengetahuan dan pemahaman tentang jurnalisme.

\section{HASIL DAN PEMBAHASAN}

\section{Eksistensi Kelompok Informasi Masyarakat Kabupaten Bandung}

Kelompok Informasi Masyarakat atau disingkat KIM adalah kelompok yang berada pada masyarakat dibentuk oleh masyarakat, dari masyarakat, dan untuk masyarakat sendiri. Mereka dituntut berdaya mandiri serta memiliki kreativitas dalam melakukan pengelolaan informasi untuk meningkatkan value. KIM berfokus pada kemampuan dan pemanfaatan informasi demi eksistensi dan pertumbuhan masyarakat sadar informasi. Apa yang didiseminasikan oleh KIM merupakan informasi yang diperlukan oleh masyarakat agar memiliki nilai efektif dalam menggunakan sumber daya yang tersedia di antara masyarakat sendiri (Sari, 2017).

Program KIM diarahkan membantu mewujudkan kelompok masyarakat yang memiliki daya guna dalam menggunakan TIK (Teknologi Informasi dan Komunikasi). Program ini juga terkait dengan penyelenggaraan penyebaran baragam informasi yang didesentralisasikan kepada masyarakat, tidak lagi berpusat pada penyelenggara kebijakan. Hal ini karena kelompok informasi masyarakat relasinya lebih dekat dengan masyarakat, mereka mengetahui apa yang menjadi kebutuhan dan keadaannya sendiri (Sari, 2017).

Memiliki peran sebagai pemberdaya informasi, anggota KIM didorong oleh dinas terkait untuk memiliki keterampilan tertentu. Sebagai dasarnya, saat menyampaikan informasi, anggota KIM menguasai dasar penyampaian informasi serta media tempat menyampaikan informasi tersebut. Jenis pesan seperti apa yang disampaikan, serta format media apa saja yang digunakan.

Jurnalisme menjadi salah satu kunci bagi anggota KIM. Era digital penggunaan media lebih diarahkan kepada digital, sehingga anggota KIM menguasai secara teknis bagaimana menyampaikan informasi melalui media digital. Oleh karena itu, pihak dinas memfasilitasi semua yang dibutuhkan berupa keterampilan-keterampilan teknis yang diperlukan oleh anggota KIM. 
Sebelum memfasilitasi keterampilan praktis tersebut, pihak dinas memberikan pemahaman berupa peran anggota kelompok masyarakat dalam melakukan pemberdayaan informasi warga. Berdasarkan peraturan pemerintah tentang Pedoman Pengembangan dan Pemberdayaan Lembaga Komunikasi Sosial, arah dibentuknya KIM sendiri: (a) mewujudkan jejaring diseminasi informasi nasional; (b) mendorong partisipasi masyarakat dalam demokrasi dan pembangunan serta sebagai upaya meningkatkan nilai tambah; (c) mendorong peningkatan kualitas media massa dan kecerdasan publik dalam mengkonsumsi informasi; dan (d) membangun masyarakat informasi (Kemenkominfo, 2010).

Peran dan fungsi KIM sebagaimana ditulis oleh Dinas Komunikasi dan Informasi Kabuten Ketapang adalah (1) Mewujudkan masyarakat yang aktif, peduli, peka dan memahami informasi; (2) Memberdayakan masyarakat agar dapat memilah dan memilih informasi yang dibutuhkan dan bermanfaat. (3) Mewujudkan jaringan informasi serta media komunikasi dua arah antara masyarakat dengan masyarakat maupun dengan pihak lainnya. (4) Menghubungkan satu kelompok masyarakat dengan kelompok yang lainnya untuk mewujudkan kebersamaan, kesatuan dan persatuan bangsa (Diskominfo, 2019).

Anggota Kelompok Informasi masyarakat Kabupaten Bandung, berdasarkan wawancara dengan kepala seksi Informasi Publik, Adhie Nur Indra memiliki 99 anggota yang sudah terdaftar. Berdasarkan hasil observasi, jumlah ini terus bertambah, seiring dengan pengembangan kapasitas yang dilakukan oleh Dinas Komunikasi dan Informasi Kabupaten Bandung. Kini anggotanya bertambah menjadi 130 orang jika berdasarkan jumlah yang tertera pada grup. Penambahan anggota berlangsung secara bertahap dan berproses.

Proses penambahan jumlah anggota KIM Kabupaten Bandung berbanding lurus dengan sosialisasi serta pelatihan-pelatihan yang dilakukan oleh Dinas Komunikasi dan Informasi atau yang dilakukan oleh pengurus KIM Kabupaten.

Pembentukkan KIM Kabupaten sendiri dilakukan secara bertahap, mulai dari sosialisasi yang dilakukan berkali-kali. Sosialisasi dilakukan dengan menghadirkan nara sumber yang ahli di bidangnya, baik yang berasal dari Bandung dan sekitarnya, ataupun kementerian terkait. Pihak Dinas Komunikasi dan Informatika secara intensif melakukan sosialisasi dan motivasi kepada anggota kelompok informasi masyarakat. Inisiasi ini telah dilakukan sejak tahun 2016.

Seiring intensitas pertemuan antara pegiat informasi ini, maka pihak dinas menginisasi membuat grup WhattsApp Group (WAG). Namun pada periode pertama inisiasi ini kurang efektif, hingga akhirnya terus digalakkan bagaimana pentingnya KIM yang diinisiasi oleh pihak dinas. Sosialisasi dilakukan mulai dari tingkat desa hingga kecamatan. Pada periode penggantian kepala dinas yang 
dipimpin oleh Ir. H. Atih Witartih, M.Si. baru terbentuk secara efektif WAG baru anggota KIM Kabupaten Bandung yang berasal dari setiap desa. Jika pada periode pertama, keanggotaan berasal dari pegiat sosial di masyarakat, yang dimasukkan kategori mitra informasi pemerintah. Sementara pada pembentukkan WAG kedua sudah fokus pada anggota kelompok informasi yang berasal dari daerah. Kedua, mulai mengarah kepada pembentukkan KIM dan membuat grup khusus WhatsApp setelah dilakukan sosialisasi KIM untuk agenagen informasi di desa ataupun tingkat kecamatan.

Setelah melalui serangkaian proses; sosialisasi, pelatihan citizen journalism, pelatihan pengelolaan media online, memfasilitasi KIM dengan web situs kimonline, dan dibentuklah kepengurusan Kelompok Informasi Masyarakat Kabupaten Bandung. Setelah dibentuk kepengurusan dan terus dilakukan pelatihan-pelatihan termasuk pelatihan Citizen Journalism bagi anggota, bagaimana pemahaman mereka tentang jurnalisme dan seberapa penting jurnalisme bagi anggota KIM. Pengurus KIM Kabupaten juga bergerilya ke desadesa untuk memberikan pelatihan jurnalistik. Pihak dinas juga memfasilitasi anggota KIM untuk terus menambah keterampilannya dalam bidang pengelolaan informasi, termasuk penguasaan perangkatnya; praktik pengambilan gambar menggunakan drone, pelatihan video editing, serta rencana lain untuk terus membekali masyarakat penggerak informasi ini agar informasi dari daerahnya masing-masing benar-benar berdaya.

Berdasarkan hasil observasi, setiap kelompok informasi masyarakat memiliki medianya masing-masing; khususnya kanal media sosial. Sedangkan media dalam format web difasilitasi oleh Dinas Komunikasi dan Informasi Kabupaten Bandung. Seperti tampak pada gambar di bawah:



Sumber: hasil observasi, kimonline.bandungkab.go.id/kim/

Gambar 1 Web KIM Kabupaten Bandung, dirujuk dari kimonline.bandungkab.go.id 
Ujang Saefullah \& Dudi Rustandi

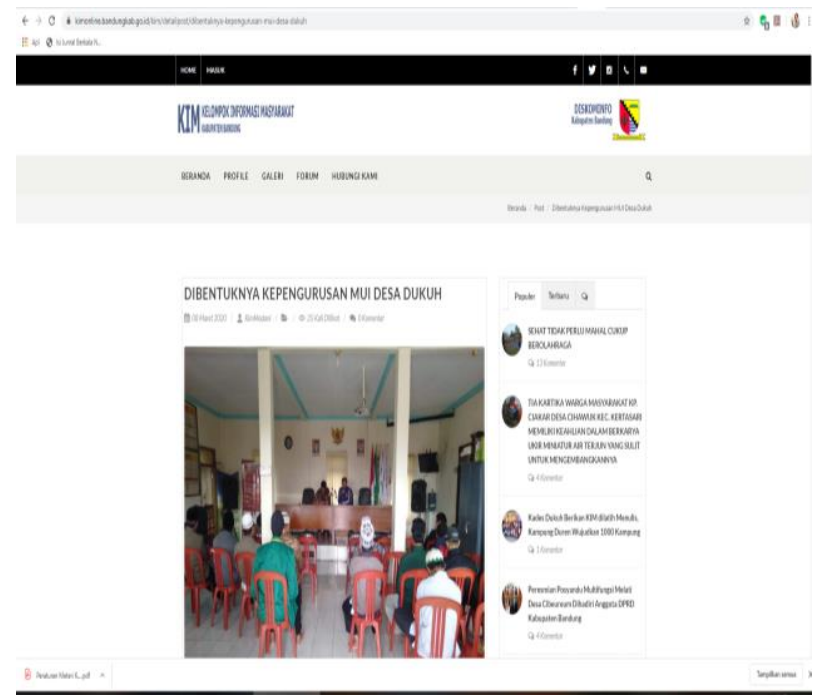

Sumber: Hasil observasi, www.kimonline.bandungkab.go.id

Gambar 2 Informasi yang dibuat oleh anggota KIM, dirujuk dari kimonline.bandungkab.go.id.

Melalui kanal media sosial, khususnya facebook dan youtube, walaupun belum efektif namun menunjukkan dilakukannya pembaharuan konten. Anggota KIM aktif berbagi informasi melalui grup facebook KIM Sabilulungan.

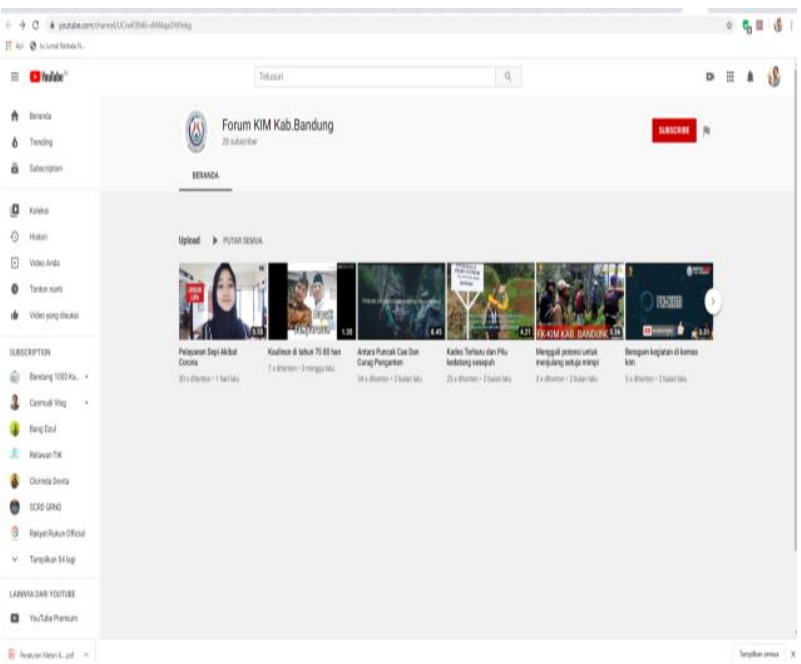

Sumber: hasil observasi, www.youtube.com/kimsabilulungan

Gambar 3: media user generated content, youtube KIM Kabupaten Bandung. 


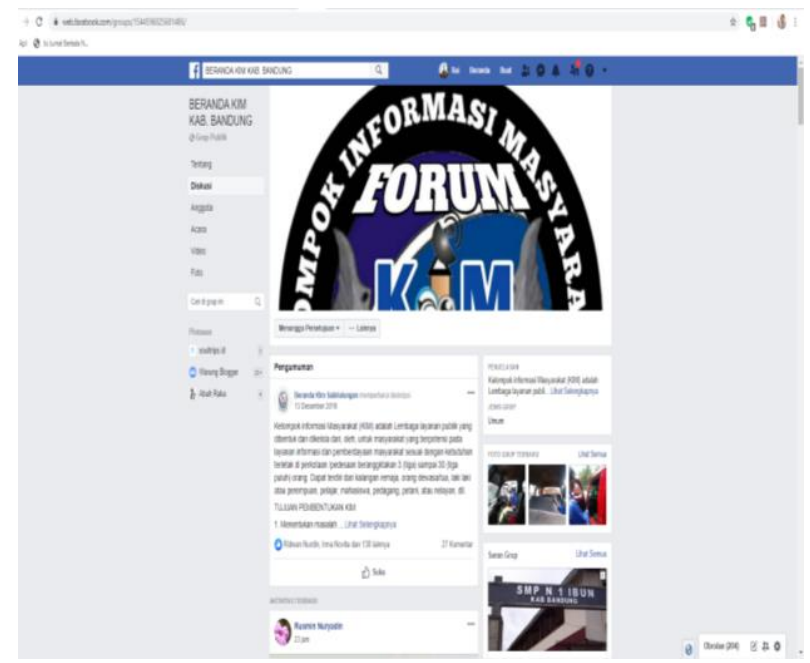

Sumber: Hasil observasi, www.facebook.com/kimsabilulungan

Gambar 4 media jejaring sosial KIM Kabupaten Bandung

Jika dibandingkan dengan KIM Kabupaten Pangandaran, seperti bisa dirujuk dari hasil penelitian Yalia (Yalia, 2015), KIM Kabupataen Bandung sudah cukup berkembangan, baik dari sisi kelembagaan, networking, ataupun pembinaan dan pengembangannya. Hal serupa, seperti yang diteliti Yalia tersebut, KIM Kabupaten Bandung, telah menggunakan TIK untuk melakukan distribusi/ publikasi informasi daerahnya masing-masing, khususnya media sosial dan media KIM yang difasilitasi oleh pemerintah daerah. Bahkan, berdasarkan perkembangan yang terjadi di dalam grup WAG, anggota KIM Kabupaten Bandung sudah diarahkan dan dibina untuk selalu melakukan literasi informasi sebelum berita disebarkan kepada yang lain. Literasi informasi merupakan kemampuan dalam memahami beragam kebutuhan informasi, termasuk di dalamnya mencari, serta menentukan informasi, membangun serta menyusun informasi secara etis untuk disajikan kepada orang lain (Nurohman, 2014). Hal ini merupakan bagian dari pengembangan keterampilan anggota KIM Kabupaten Bandung.

Anggota KIM juga selalu melakukan evaluasi terhadap setiap informasi yang masuk, seringkali melakukan konfirmasi pada grup. Apakah informasi tersebut valid atau tidak. Walaupun, sekarang telah ada media/ fasilitas untuk mengecek apakah suatu informasi benar atau hoax, hal ini dibutuhkan aplikasi yang memadai, tidak setiap informasi langsung dapat dicek pada aplikasi, maka dibutuhkan aplikasi yang dibangun secara fungsional, sehingga akan mendapatkan hasil yang sesuai harapan (Ulfah et al., 2020). Hal ini, jika merujuk pada pendapat Nurohman (Nurohman, 2014) merupakan bagian dari 
Ujang Saefullah \& Dudi Rustandi

keterampilan literasi, yaitu mengavaluasi informasi dan sumber-sumbernya secara kritis.

Hal serupa juga terjadi pada KIM di Kota Cirebon, pembinaan secara khusus belum dilakukan, sehingga berpengaruh terhadap kelangsungan organisasi. Seperti diteliti oleh Mulyono Yalia dan Noneng Sumiaty (Yalia, M. dan Sumiaty, 2019). KIM Kota Cirebon walaupun telah memiliki cukup banyak KIM namun intensitas pembinaannya masih belum dilakukan karena keterbatasan SDM termasuk kebijakan anggaran. Sedangkan KIM Kabupaten Bandung, walau keterbatasan sarana yang dimiliki, namun setiap KIM rerata difasilitasi oleh desanya masing-masing. Sehingga pemerintah daerah fokus pada pembinaan keterampilan anggota KIM.

\section{Literasi Jurnalisme Anggota KIM}

Anggota KIM merupakan agen informasi bagi daerahnya masing-masing. Untuk menyebarkan informasi, anggota KIM membekali diri dengan keterampilan dan perangkat untuk melakukan literasi informasi, salah satunya adalah pemahaman jurnalisme dan keterampilan jurnalistik. Anggota KIM berbagi informasi sesuai kaidah jurnalistik, sebagaimana yang dipahami. Namun, tidak semua paham bahwa apa yang dilakukan oleh anggota kelompok merupakan bagian dari praktik jurnalisme.

Observasi terkait dengan penelitiak ini dilakukan pada tanggal 18 Oktober 2019 terhadap kelompok informasi masyarakat. Terdapat 16 informan yang diwawancara secara daring. Mereka tersebar dari berbagai kelompok masyarakat Kabupaten Bandung, yaitu berasal dari; KIM Desa Cihawuk, KIM Desa Ciberueum, KIM, KIM Desa Ciluncat, KIM Desa Tenjolaya, KIM Desa Biru, KIM Desa Indragiri, KIM Cinunuk, KIM Bandasari.

Informan 3 beranggapan bahwa jurnalisme hanya untuk orang-orang yang sangat mengerti tentang menulis artikel, namun setelah ia mendapatkan sosialisasi dan worskhop yang difasilitasi oleh Dinas Komunikasi dan Informatika Kabupaten Bandung, menjadi paham, setiap orang dapat berbagi informasi dengan mempraktikkan jurnalisme. Hal serupa juga dikatakan oleh informan 4, ia menjadi lebih paham, dirinya dapat mempraktikkan jurnalisme saat berbagi informasi dengan warga. Begitu juga informan 5, melalui pemahaman jurnalisme dalam kontek citizen journalism, ia menjadi paham bagaimana cara menyampaikan informasi yang benar dan akurat. Informan 7, selain berpendapat hal serupa seperti yang disampaikan oleh rekan-rekannya, ia berpendapat bahwa melalui jurnalisme dalam konteks jurnalisme warga ia dapat mencari, menggali serta memublikasikan sesuai dengan kaidah seninya dengan menggali potensi yang ada di desa.

Perspektif pemahaman tentang jurnalisme secara fungsi, anggota kelompok informasi masyarakat yang diwakili oleh informan 3 dan 4 sudah 
masuk pada fase literate artinya sudah terliterasi. Hal ini sesuai dengan apa yang dikemukakan oleh Bill Kovach dan Tom Rosenstiel, jurnalisme hadir untuk membangun kewargaan. Jurnalisme eksis dalam rangka memenuhi hak-hak warga. Jurnalisme hadir untuk mendorong demokrasi. Jutaan orang, yang terberdayakan arus informasi bebas, menjadi terlibat langsung dalam menciptakan pemerintahan dan peraturan baru untuk kehidupan politik, sosial, dan ekonomi (Kovach \& Rosenstiel, 2001)

Menurut informan 1, yang berasal dari kelompok informasi masyarakat Cihawuk, jurnalisme sangat penting untuk meningkatkan nilai SDM di masyarakat. Baginya, dengan memahami jurnalisme, dapat membantu pemerintahan dalam mengelola informasi dan melaporkan peristiwa di masyarakat untuk memajukan dalam isu ekonomi, potensi, dan pembangunan. Bagi informan 2, 3 dan 15, jurnalisme sangat penting untuk menggali semua potensi yang ada di desanya. Sedangkan bagi informan 4, jurnalisme sangat penting untuk menyajikan informasi yang lebih baik. Informan 5, menganggap penting jurnalisme, yang telah dilakukannya sejak 2017, walaupun tidak tahu bahwa yang dilakukannya adalah aktivitas yang terkait dengan jurnalisme. Sementara bagi informan 6,7, 8, 9 juga sama menganggap penting. Namun, bagi informan 8, untuk dijadikan sebagai alat dalam mengangkat kegiatan-kegiatan di desa tidak bisa berdiri sendiri, harus ada dukungan dari aparat desa. Hal ini selaras dengan apa yang ditulis oleh Kovach \& Rosenstiel (2001), ia juga menegaskan tentang tujuan dari jurnalisme, yaitu menyediakan informasi yang dibutuhkan warga agar mereka bisa hidup merdeka dan mengatur diri sendiri.

Menurut informan 10 dan 11, melalui jurnalisme anggota KIM dapat menjadi penghubung masyarakat karena tidak semua peristiwa di desa dapat dijangkau oleh wartawan. Pada sisi lain, melalui jurnalisme pelayanan desa dapat optimalkan dengan memaksimalkan eksistensi web desa. Bagi informan 12, 13, 14 jurnalisme sangat penting untuk menunjang kinerja KIM di setiap desanya. Bagi informan 16, jurnalisme dapat digunakan oleh KIM agar masyarakat lebih mengetahui setiap aktivitas dari desanya.

Awak media tidak dapat menjangkau setiap wilayah karena sumber daya yang terbatas, namun melalui anggota KIM yang tersebar di daerah, mampu mengakses wilayah-wilayah terpencil, karena mereka berada pada lokasi tersebut. Hal ini selaras dengan kehadiran citizen journalism. Walaupun anggota KIM bukan wartawan, namun aktivitasnya tidak jauh berbeda dengan yang dilakukan oleh wartawan. Bagi Pepih Nugraha (Nugraha, 2012) citizen journalism adalah kegiatan warga yang tidak berprofesi sebagai wartawan beraktivitas mengumpulkan data dan fakta di lapangan atas sebuah peristiwa, menyusun, menulis, dan melaporkan hasil liputannya di media sosial. Hal ini dilakukan oleh mayoritas anggota KIM Kabupaten Bandung, yaitu berbagi melalui media sosial, selain juga mereka 
Ujang Saefullah \& Dudi Rustandi

difasilitasi oleh situs kelompoknya.

Anggota kelompok informasi masyarakat memahami bahwa jurnalisme berkaitan dengan aktivitas menulis berita yang berdasarkan pada fakta, termasuk juga melakukan pengolahan data untuk dipublikasikan kepada masyararakat. Seperti disampaikan oleh informan 1, bahwa jurnalisme adalah kegiatan jurnalistik yang menuliskan berita berupa laporan atau menulis yang dimuat pada media massa secaraa teratur. Serupa dengan yang disampaikan oleh informan 1, informan 2 dan 3 juga berpendapat bahwa jurnalisme adalah melakukan pencatatan dari peristiwa sehari-hari sesuai dengan fakta yang ada. Sedangkan informan 4 berpendapat bahwa jurnalisme adalah ilmu, teknik, dan proses yang berkenaan dengan penulisan berita. Bagi informan 5, jurnalisme adalah wartawan yang mempunyai fungsi untuk memberikan informasi yang akurat terhadap masyarakat dengan menggunakan media sosial, media cetak, dan yang lainnya. Sedangkan informan 6 dan 7 tidak memberikan pendapatnya tentang pemahamannya akan jurnalisme. Serupa apa yang disampaikan oleh Nugraha (Nugraha, 2012), pada dasarnya apa yang menjadi pemahaman mereka seirama dengan pengertian dari jurnalisme warga; mereka adalah warga biasa, bukan wartawan profesional, terkait fakta atau peristiwa yang terjadi, memiliki kemampuan menulis, memiliki semangat berbagai informasi, menayangkan hasil liputannya di blog atau media sosial, serta tidak mengharapkan imbalan. Anggota KIM tidak mendapatkan imbalan dari apa yang dilakukanya. Hal ini karena bentuk tanggung jawab terhadap daerahnya. Senada dengan pemahaman jurnalisitk dari Umar Natuna, jurnalisme (profetik) bukan hanya praktik kegiatan menulis atau melaporkan (report) setiap kejadian atau segala peristiwa disajikan dengan lengkap, lebih dari itu yakni jujur, akurat, dan bertanggung jawab (Purnama, 2019).

Menyambung pemahaman tentang jurnalisme, menurut informan 9 dan 10, merupakan kegiatan meliput, mengolah, mengambil data dan menginformasikan kepada masyarakat. Bagi informan 11, jurnalisme adalah catatan mengenai kejadian sehari-hari. Oleh karenanya seorang jurnalis adalah yang melakukan aktivitas jurnalistik dengan mencatat berbagai macam kejadian yang memiliki unsur berita dengan mengedepankan objektivitas. Informan 12, 13, 14, 15, dan 16 secara beragam memberikan pendapat bahwa jurnalisme adalah dunia pemberitaan dari kejadian sehari-hari atau moment yang dikabarkan atau diinformasikan kepada masyarakat seperti surat kabar, dan atau suatu aktivitas merencanakan, membuat dan menulis. Orang yang melakukan kegiatan atau suatu pekerjaan dengan menggunakan aspek-aspek kejurnalistikan.

Pemahaman di atas, sejalan dengan yang banyak ditulis oleh pakar jurnalistik. Asep Saeful Muhtadi merujuk pada perkembangan di Amerika memaknai jurnalisme berkaitan dengan semua kegiatan yang terkait dengan 
pemberitaan (Muhtadi, 2016). Sedangkan Zaenuddin HM menyatakan, jurnalisme berkaitan dengan hal-hal yang berhubungan dengan surat kabar, dan di dalamnya terdapat berita yang menjadi kebutuhan rakyat (HM, 2011)

Selain pemahaman tentang terkait makna jurnalisme/ jurnalistik. Untuk mengukur tingkat literate anggota kelompok masyarakat terhadap jurnalisme, maka peneliti mengajukan pertanyan tentang hal-hal yang sifatnya teknis, yaitu pada elemen dari jurnalisme, berita. Berita merupakan Salah satu produk jurnalistik. Suatu informasi dinilai sebagai berita jika mengandung unsur dan nilai berita. Terkait dengan dua hal ini, anggota kelompok informasi masyarakat cukup memahaminya. Unsur dan nilai berita dianggap penting saat seorang anggota kelompok informasi masyarakat akan menyampaikan informasi melalui medianya. Dalam ilmu jurnalistik, unsur dasar dalam penyampaian informasi ini yaitu unsur $5 \mathrm{~W} 1 \mathrm{H}$ dan nilai berita. Bagi informan 1, unsur ini sangat penting karena dengan memenuhi unsur ini maka pembaca atau masyarakat dapat memahami isi informasi. Unsur tersebut merupakan istilah umum dalam aktivitas jurnalistik dan informasi secara umum. Begitu juga dengan nilai berita, karena berita yang disampaikan harus menarik perhatian dan minat. Sehingga nilai berita juga sangat penting.

Hal tersebut senada dengan yang ditulis oleh Sedia Willing Barus yang menyatakan bahwa $5 \mathrm{~W} 1 \mathrm{H}$ merupakan pedoman dalam penulisan informasi, menjadi syarat dalam kelengkapan berita (Barus, 2010). Sedangkan menyoal nilai, Barus mengungkapkan bahwa sesuatu bernilai berita salah satunya harus penting yang dibahasakan oleh Djafar H. Assegaff sebagai interest, serupa dengan yang disampaikan oleh informan 1, yaitu menarik perhatian.

Bagi informan 2, unsur 5W1H merupakan unsur umum dalam dunia jurnalistik, tidak hanya jurnalistik, karena penulisan informasi apapun harus mengandung unsur tersebut. Sedia Willing Barus juga menyampaikan hal yang sama bahwa unsur ini tidak hanya digunakan dalam penulisan berita, juga diadaptasi oleh ilmu sosial lainnya, seperti komunikasi manajemen atau manajamen pemasaran (Barus, 2010). Unsur ini menjamin bahwa suatu informasi tersampaikan dengan baik. 5W1H menurut informan 2 merupakan kependekan dari what, where, when, who, why dan how. Melalui unsur ini, bagi informan 2, seseorang dapat memahami inti dari berita. Unsur ini menjadi sangat penting. Sedangkan terkait dengan nilai berita, informan 2 menyatakan lebih menekankan pada apa yang penting dari program-program desa yang bisa diketahui oleh warganya. Bagi informan 3, unsur berita lebih kepada bahan-bahan untuk membuat berita. Hal ini menjadi penting karena dari bahan tersebut pembaca mengetahui apa yang terjadi. Sedangkan terkait nilai, serupa dengan yang disampaikan oleh informan 2 , menekankan pada sesuatu yang penting dari program yang harus ditransparansikan oleh desa. Unsur 
penting menjadi salah satu yang ditekankan oleh Djafar H. Assegaff sebagai unsur yang harus muncul dalam berita (Barus, 2010).

Informan 4 menyatakan bahwa $5 \mathrm{w} 1 \mathrm{H}$ merupakan unsur dasar dalam penulisan berita. Unsur ini baginya sangat penting agar bisa menyajikan berita yang akurat. Terkait dengan nilai berita, informasi menjadi bernilai jika kontennya menyajikan sesuatu yang menarik dan sangat penting. Bagi informan 5, $5 \mathrm{~W} 1 \mathrm{H}$ merupakan kependekan dari what, who, where, when, why dan how. Unsur ini merupakan pokok dalam penulisan berita. Sependapat dengan informan 4, melalui pemenuhan unsur ini menjadikan informasi menjadi akurat. Sedangkan terkait dengan nilai berita, informan 5 sangat paham bahwa sebuah berita yang bernilai harus aktual, aktual menjadi faktor penentu apakah informasi tersebut memiliki nilai berita atau tidak. Menurutnya, berita akan sangat penting atau menarik bagi pembaca jika berita tersebut aktual atau masih hangat. Faktor nilai berita lainnya, menurut informan 5 adalah kedekatan. Pembaca akan lebih tertarik jika berita tersebut mengandung kedekatan dengan pembaca. kedekatan berita tersebut bisa berupa kedekatan secara geografis maupun psikologis. Aktualitas menjadi point utama yang disampaikan oleh Djafar H. Assegaff (Barus, 2010), begitu juga bagi Septiawan Santana, Baginya aktualitas menjadi patokan "kehangatan" dari kejadian dan "persaingan" media. Begitu juga kedekatan atau yang sering diistilahkan dengan proximity, menyangkut keterdekatan kejadian berita dengan pengalaman dan kepentingan khalayak (Santana, 2017).

Media yang digunakan dalam menunjang aktivitas berbagi informasi KIM Kabupaten Bandung, sebagian besar menjawab hampir media yang ada mulai dari media sosial; facebook, twitter, instagram, youtube. Mereka juga memberikan jawaban media mainstream yang bisa dijadikan sebagai media warga; koran dan TV. Sebagian lagi menjawab berdasarkan pilihan misalnya facebook, youtube, dan instagram. Ada juga yang menjawab blog, facebook, instagram, dan youtube. Sedangkan koran dan TV tidak bisa dijadikan sebagai media dalam berbagi informasi warga. Senada dengan hasil penelitian Yanuar Luqman dan Nurul Hasfi bahwa facebook dan youtube manjadi salah satu yang mendukung dalam aktivitas citizen journalisme di Indonesia, selain juga portalportal khusus dan media mainstream yang menyediakan kanalnya (Luqman \& Hasfi, 2010).

\section{Praktik Jurnalisme dalam Kelompok Informasi Masyarakat Kabupaten Bandung}

Pemahaman jurnalisme anggota kelompok informasi masyarakat Kabupaten Bandung sudah cukup baik, mulai dari pemahaman jurnalisme warga, bagaimana pentingnya jurnalisme bagi KIM, termasuk juga unsur dasar pemberitaan, dan media yang dapat digunakan untuk aktivitas berbagi informasi yang dilakukan 
oleh anggota KIM. Lalu bagaimana praktiknya, apakah pemahaman tersebut berbanding lurus dengan praktik jurnalistik di lapangan.

Hasil penelitian yang disajikan adalah berita yang diunggah pada web kimonline.bandungkab.go.id/kim. Adapun sampelnya bersifat acak sederhana, mewakili tingkat literate; kurang memiliki unsur berita dan nilai berita, tidak memiliki sama sekali, dan sudah cukup layak memiliki unsur dan nilai berita. Hal ini dilakukan selain sebagai sampel, juga perbandingan berita yang sudah literate dan belum.

Istilah literate sendiri merujuk pada tingkat apakah seseorang sudah terliterasi atau belum. Literasi awalnya membudayakan bukan sebagai kegiatan menyenangkan karena lebih merupakan sebuah upaya terorganisir untuk membentuk perilaku tertentu sebagaimana diinginkan oleh kelompok masyarakat yang berkuasa. Menurut Jack Goody (1972) seperti dikutip oleh Sofie Dewayani dan Pratiwi Ratnaningdyah, literasi diangkap variabel independen yang memberikan pengaruh terhadap kapasitas kognitif dan sosial seseorang. Pada sisi lain, literasai juga memandang membaca dan menulis sebagai proses netral, bebas konteks, dengan motivasi utama untuk mencapai melek literasi di masyarakat (Dewayani \& Retnaningdyah, 2017).Tabel 1

\begin{tabular}{lll}
\hline NO. & Isi Berita & $\begin{array}{l}\text { Unsur 5 W 1 H dan Nilai } \\
\text { berita }\end{array}$ \\
\hline 1 & $\begin{array}{l}\text { SEHAT TIDAK PERLU MAHAL CUKUP } \\
\text { BEROLAHRAGA }\end{array}$ & Unsur 5 W1H \\
KNJ - Antusias Warga dalam berolahraga masih sangat & $\begin{array}{l}\text { Apesatan } \\
\text { mendominasi, pasalnya meski Kantor Desa Neglasari }\end{array}$ & Siapa: warga Neglasari \\
$\begin{array}{l}\text { Kec. Ibun yang baru belum diresmikan sudah digunakan } \\
\text { beraktivitas oleh warga. }\end{array}$ & Kapan: 12/1/2020 \\
$\begin{array}{l}\text { "Ini disambut baik oleh masyaraka, padahal Kantor Desa } \\
\text { baru selesai dibangun tetapi warga sudah tak sabar ingin } \\
\text { menempati suasana baru," Ungkap Kepala Desa }\end{array}$ & Dimana: Neglasari Ibun \\
$\begin{array}{l}\text { Neglasari Kec. Ibun U. Wahyudin yang akrab di sapa } \\
\text { Ujang (12/1/2020). }\end{array}$ & Bagaimana: Olahraga \\
$\begin{array}{l}\text { Menurut Ujang sehat itu tidak perlu mahal, cukup } \\
\text { menyempatkan waktu sekitar 15 menit saja melakukan } \\
\text { pemanasan atau dengan berolahraga. Dengan anggota } \\
\text { badan digerakan sendi atau peredaran darah mengalir } \\
\text { dengan baik diatur dengan pola pernapasan agar jantung } \\
\text { terlatih. }\end{array}$ & Nilai berita: aktual, \\
\end{tabular}

Sampel berita anggota KIM Kabupaten Bandung

Sumber: https://kimonline.bandungkab.go.id/kim/detailpost/sehat-tidak-perlu-mahal-cukupberolahraga 
Ujang Saefullah \& Dudi Rustandi

Terkait aspek yang akan dianalisis saat merujuk pada definisi literasi, penulis menemukan makna yang tepat, seperti apa yang ditulis Dewayani dan Retnaningdyah tersebut, yakni sebagai serangkaian praktis sosial, yang bisa dirunut dari berbagai peristiwa yang melibatkan teks tertulis ((Dewayani, S. dan Retnaningdyah, 2017). Maka disinilah, pertemuan antara jurnalisme dan literasi. Bagaimana literasi jurnalisme, antara pemahaman secara kognitif harus serangkai dengan pemahaman secara praktik dalam bentuk teks tertulis, dalam hal ini berita.

Tabel 2

Sampel berita anggota KIM Kabupaten Bandung

NO. Isi Berita

2

\section{KEGIATAN BEBERSIH}

Diselenggarakannya kegiatan kebersihan di periode Tahun 2019-2020 Pemerintahan Desa Padaulun Kecamatan Majalaya Kabupaten Bandung, Kepala Desa dan jajarannya mengadakan Kegiatan Jum'at Bersih ( JUMSIH ).

Dengan sasaran lokasi yang akan dilaksanakannya kegiatan tersebut yakni berwilayah administrasi Desa Padaulun yang dimulai dari Dusun satu sampai dusun lima yang mencakup 16 Ketua Rukun Warga(RW) dan 49 Rukun Tetangga (RT).

Adapun hal manfaat dan tujuan kegiatan tersebut ialah disamping untuk kesehatan dan kebersihan yang umumnya harus wajib oleh setiap kalangan masyarakat baik kaya, menengah ataupun miskin,ada beberapa hal yang perlu dikaji kembali.
Unsur 5 W 1 H dan Nilai berita

Unsur 5W1H

Apa: kegiatan kebersihan

Siapa: aparat desa

Padaulun

Kapan: -

Dimana: Desa Padaulun

Kenapa: kesehatan dan kebersihan umum

Bagaimana: mulai dari dusun 1 sampai dusun 5 .

Nilai berita: ?

Sumber: https://kimonline.bandungkab.go.id/kim/detailpost/kegiatan-bebersih

Berita tersebut, walaupun singkat namun telah memenuhi unsur $5 \mathrm{~W} 1 \mathrm{H}$. Nilai beritanya telah terpenuhi. Sebagaimana yang diulas oleh para ahli dalam pembahasan. Jika dikaji berdasarkan konsep literasi, maka anggota KIM yang menulis berita tersebut masuk pada kategori literate, karena antara pemahaman secara konseptual dengan praktik di lapangan telah sesuai. Hal ini juga tidak terlepas dari pengalamannya menjadi penulis berita, sehingga ia terliterasi. Senada dengan Dewayani dan Retnningdyah, pengalaman literasi dimaknai sebagai rekam pengalaman seseorang dengan kegiatan membaca, menulis, dan mencerna 
pengetahuan (Dewayani, S. dan Retnaningdyah, 2017).

Setelah diurai, praktik jurnalisme ini tampak normatif. Namun terdapat satu unsur yang terlewat, yaitu waktu/ kapan. Jika salah satu unsur hilang, maka informasi menjadi tidak sempurna atau tidak lengkap. Akibatnya, informasi menjadi tidak jelas (HM, 2011). Hal ini juga pada akhirnya berpengaruh terhadap nilai berita, sehingga memuncukan pertanyaan, benarka berita tersebut faktual, benarkah aktual. Karena berita menjadi tidak jelas. Dengan demikian, tingkat literate anggota kelompok informasi masyarakat dalam mempraktikkan jurnalisme tidak seirama dengan pemahamannya terhadap jurnalisme, dengan kata lain, kurang literate.

\section{Tabel 3}

\section{Sampel berita anggota KIM Kabupaten Bandung}

\begin{tabular}{lll}
\hline NO & Isi Berita & $\begin{array}{l}\text { Unsur 5W dan Nilai } \\
\text { Berita }\end{array}$ \\
\hline 3 & $\begin{array}{l}\text { WISATA DANAU ALAM LESTARI DESA } \\
\text { PANGAUBAN }\end{array}$ & Unsur 5 W 1 H \\
$\begin{array}{l}\text { Aku ceritakan semua kebahagianku disini, danau Alam } \\
\text { Lestari, agar danau mengajariku betapa indahnya berbagi } \\
\text { tanpa harus merasa rugi. Danau ini jadi salah satu hulu } \\
\text { sungai Citarum yang membagi debet airnya di sepanjang } \\
\text { sungai yang ia lalu }\end{array}$ & Apa: Danau \\
$\begin{array}{l}\text { Dulu, danau ini nampak kumuh, namun sejak ada Satgas } \\
\text { Citarum Harum Sektor II Kodam III Siliwangi, tampilan } \\
\text { danau ini disulap menjadi lebih indah dan asri, terlebih } \\
\text { sumber mata air Danau Lestari airnya jernih dan bersih }\end{array}$ & $\begin{array}{l}\text { Kimana: } \\
\text { Kenapa: Menambah } \\
\begin{array}{l}\text { Untuk menambah daya tarik dan minat wisatawan lokal, } \\
\text { Satgas Citarum Harum menambah beberapa wahana } \\
\text { permainan bagi anak-anak, sehingga nantinya pengunjung } \\
\text { bisa betah dan menikmati suasana alam Danau Lestari } \\
\text { dengan nyaman. }\end{array}\end{array}$ & $\begin{array}{l}\text { Bagaimana: } \\
\text { menambah wahana }\end{array}$ \\
\hline
\end{tabular}

Sumber: https://kimonline.bandungkab.go.id/kim/detailpost/wisata-danau-alam-lestari-desapangauban

Ketiadaan unsur kapan dan dimana menjadikan berita ini tidak bernilai, karena dari unsur tersebutlah dapat dinilai apakah berita tersebut aktual atau faktual. Walaupun, tidak ada unsur kesengajaan untuk meniadakan unsur tersebut sehingga dapat dicurigai sebagai berita hoax. Oleh karena itulah pentingnya unsur berita yang menjadikan suatu informasi memiliki nilai. Seperti apa yang disebutkan Zaenuddin, jika tanpa ada salah satu unsur, maka informasi tersebut menjadi tidak jelas(HM, 2011). Karena menurut Barus, ketiadaan salah 
Ujang Saefullah \& Dudi Rustandi

satu unsur menjadikan informasi tersebut tidak lengkap. Ketiadaan unsur ini juga menghilangkan nilai berita. Seperti dicontohkan di atas, ketiadaan unsur 'dimana', bagi Barus yang mengutip MacDougall, maka berita kehilangan unsur jarak baik secara geografis ataupun emosional. Begitu juga dengan unsur 'kapan' menunjukkan unsur barunya kejadian demi mengejar aktualitas seperti disaratkan oleh MacDougall (Barus, 2010). Sedangkan dari sisi literasi, ketiadaan unsur sekaligus nilai berita menunjukkan bahwa antara konsep dengan praktis belum berjalan seirama, sehingga anggota KIM tersebut kurang literate.

Tabel 4

\section{Sampel berita anggota KIM Kabupaten Bandung}

\begin{tabular}{|c|c|c|}
\hline NO. & Isi Berita & $\begin{array}{l}\text { Unsur } 5 \mathrm{~W} 1 \mathrm{H} \\
\text { dan Nilai berita }\end{array}$ \\
\hline \multirow{4}{*}{4} & $\begin{array}{l}\text { KADES DUKUH BERIKAN KIM DILATIH MENULIS, } \\
\text { KAMPUNG DUREN WUJUDKAN } 1000 \text { KAMPUNG }\end{array}$ & Unsur 5W $1 \mathrm{H}$ \\
\hline & $\begin{array}{l}\text { Dukuh - Dalam upaya mewujudkan pembangunan Nasional, } \\
\text { Kepala Desa Dukuh libatkan kaum Milenial turut serta } \\
\text { berkontribusi terhadap pembangunan Nasional. Melalui } \\
\text { pemberdayaan masyarakat yang tergabung dalam Kelompok } \\
\text { Informasi Masyarskat (KIm) Madani. Kaum milenial ini di } \\
\text { berikan pembinaan sekaligus pelatihan agar menjadi berdaya, } \\
\text { dilatih menulis artikel, diberikan pemahaman cara menggunakan } \\
\text { android yang positif dan website libatkan Diskominfo } \\
\text { Kab.Bandung. }\end{array}$ & $\begin{array}{l}\text { Apa : Pelatihan } \\
\text { menulis } \\
\text { Siapa: Kepala } \\
\text { Desa Dukuh } \\
\text { Kapan: } \\
\text { Dimana: } \\
\text { Kenapa: }\end{array}$ \\
\hline & $\begin{array}{l}\text { Kepala Desa Dukuh Yanto Erawanto mengakatakan, pelatihan } \\
\text { ini dipandang perlu agar mereka kaum milenial tidak salah } \\
\text { kaprah dalam menggunakan android, selain itu mereka juga } \\
\text { harus bisa membedakan mana informasi yang benar, bijak dalam } \\
\text { ber media sosial. Disamping itu dengan adanya KIM ini sangat } \\
\text { setelah dipahami bernilai positif bisa memberdayakan } \\
\text { masyarakat bisa menggali potensi unggulan di setiap RW bisa } \\
\text { terangkat," selanjutnya kata Ketua Apdesi Kecamatan Ibun ini. }\end{array}$ & $\begin{array}{l}\text { Pemberdayaan } \\
\text { kaum milenial } \\
\text { Bagaimana: } \\
\text { Dukungan pemdes } \\
\text { kegiatan baik dan } \\
\text { lancar }\end{array}$ \\
\hline & $\begin{array}{l}\text { "Nah, dengan adanya KIM ini justru menguntungkan, bisa } \\
\text { membantu pemerintah desa sebagai teman atau mitra dalam } \\
\text { menyampaikan informasi kepada masyarakat, bisa meng handle } \\
\text { penyebaran berita bohong," terang Yanto yang akrab disapa } \\
\text { Atot. }\end{array}$ & Nilai berita: \\
\hline
\end{tabular}

Sumber: https://kimonline.bandungkab.go.id/kim/detailpost/kades-dukuh-berikan-kim-dilatihmenulis-kampung-duren-wujudkan-1000-kampung

Literate-nya seorang anggota KIM, tidak ditunjukkan oleh panjang lebarnya 
tulisan, namun menekankan pada kelengkapan unsur dan penunjang nilai berita. Senada dengan tabel 2, contoh berita pada tabel 3 ini menunjukkan konsep jurnalisme belum berbanding lurus dengan praktik jurnalisme di lapangan, khususnya saat dituangkan dalam bentuk tulisan.

Tabel 5

Sampel berita anggota KIM Kabupaten Bandung

\begin{tabular}{|c|c|c|}
\hline NO & Isi Berita & $\begin{array}{l}\text { Unsur } 5 \mathrm{~W} 1 \mathrm{H} \text { dan } \\
\text { Nilai Berita }\end{array}$ \\
\hline \multirow[t]{8}{*}{5} & $\begin{array}{l}\text { Peresmian Posyandu Multifungsi Melati Desa Cibeureum } \\
\text { Dihadiri Anggota DPRD Kabupaten Bandung }\end{array}$ & $\begin{array}{l}\text { Unsur 5W } 1 \mathrm{H} \text { dan } \\
\text { Nilai Berita }\end{array}$ \\
\hline & $\begin{array}{l}\text { Ketua TP PKK Desa Cibeureum, Epi Farida, A.M.Keb } \\
\text { Meresmikan Posyandu Multifungsi di Kampung Cihalimun } \\
\text { RW } 04 \text { Desa Cibeureum Kecamatan Kertasari (11/2). }\end{array}$ & $\begin{array}{l}\text { Apa: Peresmian } \\
\text { Posyandu } \\
\text { Siapa: Ketua TP PKK }\end{array}$ \\
\hline & $\begin{array}{l}\text { Peresmian posyandu multifungsi Melati ini berjalan sederhana } \\
\text { namun disambut antusias oleh masyarakat. Peresmian gedung } \\
\text { posyandu ini ditandai dengan gunting pita oleh ketua TP PKK }\end{array}$ & $\begin{array}{l}\text { Desa Cibeureum } \\
\text { Kapan: } 11 / 2 / 2020\end{array}$ \\
\hline & $\begin{array}{l}\text { Desa Cibeureum. } \\
\text { Dalam sambutan Sekretaris Desa Cibeureum, Agus Candra }\end{array}$ & $\begin{array}{l}\text { Dimana: Kampung } \\
\text { Cihalimun. }\end{array}$ \\
\hline & $\begin{array}{l}\text { Ningrat mengatakan, bahwa posyandu ini bisa menjadi tempat } \\
\text { pelayanan untuk masyarakat. Selain itu, posyandu juga bisa } \\
\text { digunakan untuk ronda malam atau pun rapat-rapat } \\
\text { masyarakat sekitar. }\end{array}$ & $\begin{array}{l}\text { Kenapa: agar bisa } \\
\text { mewujudkan } \\
\text { masyarakat yang sehat }\end{array}$ \\
\hline & $\begin{array}{l}\text { "Diharapkan ke depannya posyandu ini bisa digunakan untuk } \\
\text { melayani masyarakat untuk mewujudkan masyarakat yang } \\
\text { sehat dan mewujudkan visi misi Pemerintah Desa Cibeureum } \\
\text { yaitu PANTES (Produktif, Agamis, Nyaman dan SEHAT)," } \\
\text { ujar Agus Candra Ningrat, senin }(11 / 2) .\end{array}$ & \multirow{2}{*}{$\begin{array}{l}\text { Bagaimana: Peresmian } \\
\text { berjalan sederhana dan } \\
\text { masyarakat antusias } \\
\text { Nilai berita: aktual, } \\
\text { faktual, menarik. }\end{array}$} \\
\hline & $\begin{array}{l}\text { Sementara itu Anggota DPRD Kabupaten Bandung, KH. } \\
\text { Wawan Sopwan Hadi yang juga sebagai masyarakat setempat } \\
\text { menyambut sangat gembira diresmikannya posyandu } \\
\text { multifungsi Melati ini karena akan memudahkan masyarakat } \\
\text { untuk mendapatkan pelayanan kesehatan. }\end{array}$ & \\
\hline & $\begin{array}{l}\text { Kepala Dusun Cihalimun, Yogi Rahmat juga mengatakan } \\
\text { sangat bersyukur telah diresmikannya posyandu multifungsi } \\
\text { melati ini karena memang sudah sangat lama diharapkan oleh } \\
\text { masyarakat kampung Cihalimun RW } 04 \text {. }\end{array}$ & \\
\hline
\end{tabular}

Sumber:https://kimonline.bandungkab.go.id/kim/detailpost/peresmian-posyandu-multifungsimelati-desa-cibeureum-dihadiri-anggota-dprd-kabupaten-bandung.

Kelengkapan unsur berita, seperti yang tertera pada sampel berita pada tabel 5, berdampak terhadap kemunculan nilai berita, selain aktual yang dirujuk 
Ujang Saefullah \& Dudi Rustandi

dari unsur 'kapan', kedekatan yang dirujuk dari unsur 'dimana'. Gabungan semua unsur memunculkan nilai, apakah berita tersebut faktual atau tidak. Apakah berita tersebut merujuk pada fakta yang ada. Fakta menunjukkan objektivitas sebuah berita. Fakta ini menjadi prinsip dalam literasi jurnalisme. Seperti ditulis oleh Septiawan Santana K. Dari fakta, objektivitas menjadi salah satu fakta jurnalisme Keojektivannya di antaranya melaporkan fakta. Fakta-fakta yang dilaporkan oleh publisher, membantu masyarakat memahami kejadian yang memengaruhi kehidupan mereka (Santana, 2017).

Kemelekan terhadap jurnalisme, meminjam redaksi dari Yosal Iriantara, adalah tindakan yang dilakukan untuk menjaga media agar tetap menjalankan fungsinya di tengah masyarakat (Iriantara, 2009). Jika anggota KIM telah literate atau jurnalismenya telah terliterasi, maka seperti ditulis oleh Yosal Iriantara, akan bisa memberi arah terhadap pelaksanaan fungsi media secara bebas yang demokratis. Mereka memiliki kesempatan untuk ikut serta dalam mencerdaskan kehidupan bangsa (Iriantara, 2009).

\section{PENUTUP}

Merujuk pada hasil dan pembahasan penelitian, disimpulkan, eksistensi KIM Kabupaten Bandung diinisasi tahun 2016, yang dinisiasi oleh Dinas Komunikasi dan Informatika Kabupaten Bandung, didukung pada tahun 2019 dengan pemebtukan pengurus serta fasilitasi media KIM berupa website dan media sosial. Hal ini merujuk pada peraturan kementerian KOMINFO bahwa setiap daerah sampai tingkat desa diwajibkan memiliki kelompok sosial yang bergerak dalam bidang informasi.

Pada dasarnya sebagian besar anggota kelompok Informasi Masyarakat Kabupaten Bandung telah memiliki pemahaman yang cukup baik tentang apa itu jurnalisme, kenapa harus mempraktikkan jurnalisme dalam aktivitasnya sebagai anggota KIM ketika menyelenggarakan praktik-praktik penyebaran informasi. Dari sisi teknik pengetahuan juga sudah cukup memadai, mereka paham tentang 5W1H, paham tentang nilai berita. Pemahaman ini hampir merata pada anggota yang berhasil diwawancarai yaitu 16 anggota KIM Kabupaten Bandung, namun pada praktinya, pemahaman yang mereka miliki tidak berbanding lurus dengan praktik di lapangan.

Hanya saja, merujuk pada praktik jurnalisme dalam bentuk penyebaran informasi berupa tulisan atau video, pemahaman jurnalisme tersebut tidak linear dengan praktik jurnalismenya. Terjadi gap antara pengetahuan dan pemahamannya tentang jurnalisme dengan praktik di lapangan. Sebagian kecil anggota KIM telah mempraktikkan jurnalisme dengan baik, namun sebagian besar masih jauh dari kriteria jurnalisme. Artinya, sebagian dari mereka baru sebatas paham, namun belum bisa secara praksis direalisasikan dalam bentuk tulisan yang sesuai dengan kaidah penulisan jurnalistik. Hanya sebagian kecil 
yang telah terliterasi, atau masuk pada kategori literate. Berkelindannya antara pemahaman secara konsep dengan praktik di lapangan.

Penelitian ini dapat menjadi pijakan bagi dinas terkait atau pengurus KIM Kabupaten Bandung untuk terus meningkatkan pembinaanya, sehingga tingkat literate jurnalisme anggota KIM merata di semua kelompok.

\section{DAFTAR PUSTAKA}

Azizah, N. (2018). Difusi Inovasi dalam Konteksperanan Kelompok Informasi Masyarakat (Kim) Swara Ringgitkelurahan Ledug Guna Meningkatkan Potensi Lokal. Heritage, 6(2), 30-37. https://doi.org/https://doi.org/ 10.35891/heritage.v6i2.1567

Barus, S.W. (2010). Jurnalistik, Petunjuk Teknis Menulis Berita. Jakarta: Penerbit Erlangga.

Dewayani, S., \& Retnaningdyah, P. (2017). Suara dari Marjin: Literasi sebagai Praktik Sosial. Bandung: PT Remaja Rosdakarya

Diskominfo. (2019). Pengembangan dan Pemberdayaan Kelompok Informasi Masyarakat. Dinas Komunikasi Dan Informasi Kabupaten Katapang. https:/ / diskominfo.ketapangkab.go.id/2019/08/07/pengembanganpemberdayaankelompok-informasi-masyarakat-kim/

Dinas Komunikasi dan Informatika Kabupaten Kolaka. (2010). Pengertian Komunikasi dan Informatika Kabupaten (KIM). Diakses tanggal 2 Juni 2020, dari https:/ kim.kolakakab.go.id/pengertian-kim/

Fadillah, A. K., \& Cahyana, R. (2017). Pengembangan Portal Web Kelompok Informasi Masyarakat. Algoritma, 14 (1), 96-100. https://doi.org/10.33364 Lalgoritma/v.14-1.96

HM, Z (2011) The Journalist: Bacaan Wajib Wartawan, Redaktur, Editor, dan Mahasiswa Jurnalistik. Bandung: Simbiosa Rekatama Media.

Iriantara, Y. (2009). Literasi Media; Apa, Mengapa, Bagaimana. Bandung: Simbiosa Rekatama Media.

Kementerian Komunikasi dan Informatika (2010) Peraturan Menteri Komunikasi dan Informatika RI No. 08/PER/M.KOMINFO/ 6/2010 tentang Pedoman Pengembangan dan Pemberdayaan Lembaga Komunikasi Sosial.

Diakses 12 Maret 2020 dari jdih.kominfo.go.id

Kovach, B. Dan Rosenstiel, T. (2001). The Element of Journalism: What Newspeople Should Know and The Public Should Expect. New York: Crown Publishers.

Luqman, Y. \& Hasfi, N. (2010) Citizen Journalisme, dalam Jurnal Forum, 2 (2): 1 63. https://ejournal.undip.ac.id/index.php/forum/article/view/271/ 173.

Muhtadi, A.S. (2016). Pengantar Ilmu Jurnalistik, Bandung: Simbiosa Rekatama Media.

Nugraha, P. (2012). Citizen Journalism; Pandangan, Pemahaman, dan Pengalaman. 
Ujang Saefullah \& Dudi Rustandi

Jakarta: Penerbit Buku Kompas.

Nurohman, A. (2014). Signifikansi Literasi Informasi (Information Literacy) dalam Dunia Pendidikan di Era Global, Jurnal Kependidikan, 2 (1):1-25. DOI: $10.24090 /$ jk.v2i1.537.

Purnama, F. (2019). Pemikiran Parni Hadi tentang Jurnalisme, dalam Communicatus: Jumal Ilmu Komunikasi, 3 (1) (2019) 35-52. DOI: 10.15575/cjik.v3i1.5035

Santana, S. (2017). Jurnalisme Kontemporer Edisi 2. Jakarta: Yayasan Obor Indonesia.

Sari, R. P. (2017). Pencapaian Masyarakat Informasi Ditinjau Melalui Implementasi Program Kelompok Informasi Masyarakat (KIM): Studi Kasus Implementasi Program Kim Di Jawa Timur. Berkala Ilmu Perpustakaan Dan Informasi, 13(1), 56-63. doi: http://10.22146/bip.26042

Ulfah, S., Ramdania, D. R., Fatoni, U., \& Muchtar, K. (2020). Augmented reality using Natural Feature Tracking ( NFT) method for learning media of makharijul huruf Augmented reality using Natural Feature Tracking ( NFT ) method for learning media of makharijul huruf. IOP Conf. Series: Materials Science and Engineering, 1-6. https://doi.org/10.1088/1757899X/874/1/012019

Wiranti, N. Y., \& Aji, G. G. (2019). Praktik jurnalisme warga dalam kelompok informasi masyarakat (KIM) kota surbaya. Commercium, 2(2), 24-28. https://jurnalmahasiswa.unesa.ac.id/index.php/Commercium/article/ view $/ 29145$

Yalia, M. (2015). Implementasi Kebijakan Pengembangan dan Pemberdayaan Lembaga Komunikasi Sosial (Studi Pada Kelompok Informasi Masyarakat (KIM) Di Kabupaten Pangandaran Jawa Barat), Jurnal Penelitian Komunikasi dan Opini Publik, 19 (1): 29-41. http://jurnal.kominfo.go.id/index.php/ jpkop/article/download/334/270.

Yalia, M., \& Sumiaty, N. (2019). Kebijakan Pengembangan dan Pemberdayaan Lembaga Komunikasi Sosial Kelompok Informasi Masyarakat, Dialektika; Jurnal Ilmu Komunikasi, 6 (2): 150-163. http://journal.unla.ac.id/index.php/ dialektika/article/view/1263

Yudhistiro, K., \& Sonalitha, E. (2019). Pembentukan Kelompok Informasi Masyarakat Kelurahan Gadingkasri, Kota Malang. 2 (November), 14-19. http://jmm. unmerpas.ac.id/ index.php/jmm/article/view/23/20 